\title{
Correlation between Blood Biochemical Metabolites Milk Yield, Dry Matter Intake and Energy Balance in Dairy Cows during Early and Mid Lactation
}

\author{
Radojica Djoković ${ }^{1, *}$, Vladimir Kurćubić ${ }^{1}$, Zoran Ilić ${ }^{2}$, Marko Cincović ${ }^{3}$, Miroslav Lalović ${ }^{4}$, \\ Boban Jašović ${ }^{2}$ Jovan Bojkovski ${ }^{5}$ \\ ${ }^{1}$ Department of Animal Science, Faculty of Agronomy, University of Kragujevac, Serbia \\ ${ }^{2}$ Department of Animal Science, Faculty of Agronomy, University of Prishtina, Serbia \\ ${ }^{3}$ Department of Veterinary Medicine, Faculty of Agriculture, University of Novi Sad, Serbia \\ ${ }^{4}$ Department of Animal Science, Faculty of Agriculture, University of East Sarajevo, Bosnia and Herzegovina \\ ${ }^{5}$ Department of Farm Animals, Faculty of Veterinary Medicine, University of Belgrade, Serbia
}

Copyright $\bigcirc 2017$ by authors, all rights reserved. Authors agree that this article remains permanently open access under the terms of the Creative Commons Attribution License 4.0 International License

\begin{abstract}
The objective of the present study was to investigate nutritional and metabolic status in Simmental cows during early and mid-lactation. Fifteen early lactation cows and 15 mid lactation cows were chosen for the analysis. Blood samples were collected to measure beta-hydroxybutyrate (BHB), non-esterified fatty acids (NEFA), triglycerides (TG), glucose and the activity of aspartate transaminase (AST). Blood metabolites, milk yield, dry matter intake (DMI) and energy balance (EB) were recorded. Correlation analysis showed that DMI was significantly negatively correlated with NEFA, BHB and AST, and positively with glucose and TG. EB was significantly negatively correlated with NEFA, BHB and AST, and positively with glucose. Early lactation as compared to mid lactation cows were found to have significantly higher blood serum concentrations of NEFA, BHB and AST activities and lower blood serum concentrations of glucose and TG, but not significant. These metabolic changes were in correlation with DMI and EB, but not with milk yield. Suggest that they can serve as useful indicators of the nutritional and metabolic status of dairy cows during lactation.
\end{abstract}

Keywords Blood Metabolites, Dry Matter Intake, Energy Balance, Dairy Cows

\section{Introduction}

Production diseases i.e. diseases associated with improper nutrition or management are common in dairy cows. Dairy cows suffer from negative energy balance (NEB) during the first weeks of lactation due to energy expenditure associated with milk production and limited feed intake, resulting high mobilization of lipids from body fat reserves, and hypoglycaemia $[1,2,3,4,5]$.Nutrition, age, heredity, body condition score (BCS), management and energy imbalance as various risk factors are possible causes of NEB, periparturient fatty liver and ketosis [5, 6, 7]. Clinical ketosis in dairy cows usually occurs between the second and seventh week of lactation. Nevertheless, most of cows in this stage of lactation may suffer a subclinical form of ketosis defined as increased blood ketone bodies without any other symptoms but accompanied by considerable decrease in milk yield and susceptibility other diseases[8]. The degree of NEB in early lactation and the recovery rate from are critical for health status and productivity [5, 9]. Various metabolic and endocrine blood and milk traits have been shown to relate to EB [9]. Consequently, stressors and poor nutritional management causing reduction in voluntary DMI will result in large increases in NEFA around calving [2]. The main blood indicators of lipomobilization in ruminants are BHB, the most important and abundant ketone body, and NEFA [3, $10,11]$.NEFA are preferentially and greatly accumulated as TG in the liver, primarily because of a decrease in the very low density lipoproteins (VLDL) synthesis by hepatocytes $[12,13]$.However, when steatosis occurs, endogenous liver synthesis decreases, leading to a reduction in blood glucose, total proteins, albumins and globulins, cholesterol, TG and urea. $[1,3,4,13,14]$.Fatty liver infiltration and hepatocyte degeneration involve cell membrane damage and hepatocyte destruction coupled with the release of cytoplasm enzymes (AST, GGT, LDH) and marked increases in the circulating activities $[7,15]$.

The objective of the present study was to investigate nutritional and metabolic status in Simmental cows during 
early and mid-lactation on the basis the correlations between blood biochemical metabolites, milk yield, DMI and EB.

\section{Material and Methods}

\section{Animals, Diets and Protocol Design}

This experiment was carried out in January 2012 in a dairy herd (166 Simmental cows) suffering from several metabolic and reproductive disorders (Farm: Miličić-Ćurćić, Mrsać, Kraljevo, Central Serbia). Two groups ( $\mathrm{n}=15$ cows in each group) of clinically healthy cows were chosen from the herd. The cows were mid-yielding with a preceding lactation of about 65001 and $25 \pm 5$ 1/day (early lactation cows: 6488 \pm 980 , and 23 \pm 4 ); mid lactation cows cows: $6677 \pm 1088$ and $28.5 \pm 6$ ). Group 1 consisted of early lactation cows, in the first month of lactation (16.1 \pm 9.3 days), and Group 2 included mid lactation cows between 3 to 5 months of lactation (114.8 \pm 28.5 days). The cows were aged 4-6 years on average, weighing $595.21 \pm 48.27 \mathrm{~kg}$ in groups of cows in early lactation and $635.28 \pm 55.52 \mathrm{~kg}$ in groups of cows in mid lactation. The body condition scores (BCS) of the test cows were $3.2-4$, according to Ferguson et al. [16]. The insemination index of the experimental cows was 2.15 . The experimental cows were kept in tie-stall barns. Diet and the housing facilities were adapted to research purposes, with diet suited to the energy requirement of early and mid-lactation cows. Early lactation cows were fed a diet consisting of $7 \mathrm{~kg}$ lucerne hay, $20 \mathrm{~kg}$ maize silage (30\% Dry Matter, DM), $5 \mathrm{~kg}$ concentrate (18\% crude proteins, CP). Mid lactation cows received a diet consisting of $5 \mathrm{~kg}$ hay, 7 $\mathrm{kg}$ lucerne hay, $30 \mathrm{~kg}$ maize silage $(30 \% \mathrm{DM}), 8 \mathrm{~kg}$ concentrate $(18 \% \mathrm{CP})$. Dietary nutrient contents for dairy cows in early and mid-lactation are given in Table 1 . The chemical analysis of the feed was performed by Weende methodology. Energy balance was calculated by NRC recommendation [17].

\section{Biochemical Analysis}

Blood samples were collected at 10:00 h or 4 to 6 hours after milking and feeding, by puncture of the jugular vein into sterile disposable test tubes, without anticoagulant. After clotting for 3 hours at $4^{\circ} \mathrm{C}$ and centrifugation $(1500 \mathrm{~g}$, 10 minutes, $4^{\circ} \mathrm{C}$ ), sera were carefully harvested and stored at $-20^{\circ} \mathrm{C}$ until analysis. Blood samples collected on fluoride were immediately centrifuged in the same manner and plasmas were assessed for glucose concentrations. The following biochemical blood components were measured at
Kvarklab Biochemical Laboratory (Kragujevac, Serbia) by different colorimetric techniques using spectrophotometers (Cobas Mira and Gilford Stasar): BHB and NEFA levels were measured by Randox (United Kingdom) kit, AST and glucose by Human (Germany) kit, and TG by Elitech (France) kit.

\section{Statistical Analysis}

Data were subjected to statistical analysis using the GLM model and t-test (Statgraphic Centurion, Statpoint Technologies Inc. Warrenton, Va, Virginia, USA). The model included lactation period and metabolite values. Pearson's test was performed to evaluate significant correlations between milk yield, DMI, EB and biochemical metabolites separately. The intensity of change in metabolic profile during negative energy balance in early and mid-lactation stages was analyzed by comparison of $b$ parameters in linear equations (t-test). Finally, correlation between metabolic parameters was evaluated. Differences were considered significant at $P$ values below 0.05 or 0.01 .

\section{Results}

Results on blood biochemical metabolites for both groups of cows are shown in Table 2.

Significant changes in most blood metabolites between the experimental groups of cows were found. Blood glucose concentration was significantly lower $(\mathrm{P}<0.05)$ in early lactation cows as compared to mid lactation cows. Biochemical testing for lipids and ketone bodies in the blood serum showed significantly higher values $(\mathrm{P}<0.05)$ of NEFA and BHB in early lactation cows as compared to those in the blood sera of mid lactation cows. In addition, AST activities were markedly increased in puerperal cows compared to mid lactation females $(\mathrm{P}<0.05)$. Mean values for blood TG in early lactation cows were lower, but no significant differences between the two groups.

The metabolic levels significant correlated with DMI and EB and did not significant correlated with milk production (Table 3).

Change of metabolites as a function of EB in early and mid-lactation is shown in Table 4. The values changed much more intensely in early lactation than in mid lactation. The decrease in energy balance led to increased NEFA, BHB and AST and decreased glucose levels for every unit change much more intensely in early lactation than in mid lactation. 
Correlation between Blood Biochemical Metabolites Milk Yield, Dry Matter Intake and Energy Balance in Dairy Cows during Early and Mid Lactation

Table 1. Nutrient contents in daily ration for early lactation and mid lactation dairy cows

\begin{tabular}{|c|c|c|}
\hline & Early lactation cows & Mid lactation cows \\
\hline Dry Matter (DM) (kg) & 16.05 & 24.82 \\
\hline Net Energy of Lactation (NEL) (MJ) & 87.15 & 130.23 \\
\hline Crude Protein $(\mathrm{CP})(\%$ of DM) & 13.58 & 13.38 \\
\hline Rumen undegradable protein (RUP) (\% of CP) & 35.91 & 28.33 \\
\hline Fat $(\%$ of DM) & 3.09 & 3.14 \\
\hline Fiber $(\%$ of DM) & 23.26 & 24.33 \\
\hline $\mathrm{EB}(\mathrm{MJ} /$ day/cow $)$ mean $\pm \mathrm{SD}$ & $-15.21 \pm 20.37$ & $3.49 \pm 8.16$ \\
\hline
\end{tabular}

Table 2. Blood metabolites in early and mid-lactation dairy cows ( $\mathrm{n}=15$ in each group). Results are expressed as mean \pm standard deviation (SD).NS: non-significant

\begin{tabular}{|c|c|c|c|}
\hline & Early lactation cows & Mid lactation cows & P \\
\hline Glucose $(\mathrm{mmol} / \mathrm{l})$ & $2.29 \pm 0.48$ & $2.76 \pm 0.43$ & $<0.05$ \\
\hline BHB $(\mathrm{mmol} / \mathrm{l})$ & $1.59 \pm 0.25$ & $0.91 \pm 0.16$ & $<0.05$ \\
\hline NEFA $(\mathrm{mmol} / \mathrm{l})$ & $0.38 \pm 0.29$ & $0.13 \pm 0.04$ & $<0.05$ \\
\hline TG $(\mathrm{mmol} / \mathrm{l})$ & $0.12 \pm 0.02$ & $0.15 \pm 0.04$ & NS \\
\hline AST $(\mathrm{U} / \mathrm{l})$ & $69.46 \pm 27.54$ & $39.31 \pm 18.90$ & $<0.05$ \\
\hline
\end{tabular}

Table 3. Correlation coefficients between metabaolites and milk production, DMI and EB. Significant correlations $(\mathrm{p}<0.05)$ are marked with asterix $(*)$.

\begin{tabular}{|c|c|c|c|}
\hline Metabolites & $\begin{array}{c}\text { Milk } \\
(1 / \text { day })\end{array}$ & $\begin{array}{c}\text { DMI } \\
(\text { cow/day })\end{array}$ & EB (MJ/day) \\
\hline Glucose & $\mathrm{r}=0.18$ & $\mathrm{r}=0.43^{*}=0.45^{*}$ \\
\hline NEFA & $\mathrm{r}=-0.21$ & $\mathrm{r}=-0.50^{*}$ & $\mathrm{r}=-0.49^{*}$ \\
\hline BHB & $\mathrm{r}=-0.25$ & $\mathrm{r}=-0.38^{*}$ & $\mathrm{r}=-0.53^{*}$ \\
\hline TG & $\mathrm{r}=-0.11$ & $\mathrm{r}=0.42^{*}$ & $\mathrm{r}=0.18$ \\
\hline AST & $\mathrm{r}=0.07$ & $\mathrm{r}=-0.49^{*}$ & $\mathrm{r}=-0.41^{*}$ \\
\hline
\end{tabular}

Table 4. Change of metabolites as a function of EB in early and mid-lactation (comparison of $b$ parameters from linear equation). NS: non-significant

\begin{tabular}{|c|c|c|c|}
\hline \multirow{2}{*}{ Metabolites } & \multicolumn{2}{|c|}{$\begin{array}{c}\text { b parameters } \\
\text { (relation EB to metabolite) }\end{array}$} & \multirow{2}{*}{ P } \\
\cline { 2 - 4 } & Early lactation & Mid \\
& lactation & $<.05$ & $<0.05$ \\
\hline Glucose & 0.08 & -0.03 & $<0.01$ \\
\hline NEFA & -0.07 & -0.05 & $<0.01$ \\
\hline BHB & -0.09 & 0.003 & NS \\
\hline TG & 0.002 & -2.28 & $<0.01$ \\
\hline AST & -4.35 & 0.01 \\
\hline
\end{tabular}

Table 5. Correlation coefficients for the biochemical metabolites calculated for all cows in the present study. Significant correlations $(\mathrm{p}<0.05)$ are marked with asterix $(*)$.

\begin{tabular}{|c|c|c|c|c|}
\hline & NEFA & BHB & TG & AST \\
\hline Glucose & $\mathrm{r}=-0.35^{*}$ & $\mathrm{r}=-0.47^{*}$ & $\mathrm{r}=0.65^{*}$ & $\mathrm{r}=-0.23$ \\
\hline NEFA & & $\mathrm{r}=0.39^{*}$ & $\mathrm{r}=-0.21$ & $\mathrm{r}=0.34^{*}$ \\
\hline BHB & & & $\mathrm{r}=-0.36^{*}$ & $\mathrm{r}=0.15$ \\
\hline TG & & & & $\mathrm{r}=-0.04$ \\
\hline
\end{tabular}


The correlation coefficients among the biochemical parameters calculated for all cows in this experiment are summarized in Table 5. Significantly negative correlations $(\mathrm{P}<0.05)$ were observed between $\mathrm{BHB}$ and glucose, $\mathrm{BHB}$ and TG, NEFA and glucose. Significantly positive correlations $(\mathrm{P}<0.05)$ were observed between NEFA and BHB, NEFA and AST, glucose and TG.

\section{Discussion}

Blood biochemical metabolites, milk yield, DMI and EB in early lactation and mid lactation cows were compared in this study. Homeorhesis induces intense lipid mobilization and ketogenesis, and the liver is adapted to metabolic changes in dairy cows. Intensive postpartum lipid mobilization and ketogenesis are sufficient for a series of compensatory metabolic processes with changes in blood metabolic profile during early lactation in healthy cows [2, 5, 18].In early lactation cows, NEFA and BHB values were significantly higher than in mid lactation cows. NEFA concentrations $>0.40 \mathrm{mmol} / \mathrm{l}$ indicate problems with energy balance and subsequent intensive lipomobilization [3]. According to this report, in early lactating cows, NEFA values in blood were $0.38 \pm 0.29 \mathrm{mmol} / 1$, showing evidence of high lipomobilization in the present study. Given the fact that serum NEFA concentrations $>0.70 \mathrm{mmol} / \mathrm{l}$ are associated with ketosis [3]. These are result the some early lactating cows in the present study had NEFA concentrations above the value indicative of subclinical ketosis. Subclinical ketosis also may be diagnosed when serum BHB concentrations are above $1.2 \mathrm{mmol} / \mathrm{l}$, while clinical ketosis is associated with BHB concentrations above $2.6 \mathrm{mmol} / \mathrm{l}$ [3, 19]. These are result early lactating cows in the present study had BHB concentrations above the value indicative of subclinical ketosis $(1.59 \pm 0.25 \mathrm{mmol} / \mathrm{l})$. The data presented show that serum NEFA may be used for detecting high lipomobilization, but not subclinical ketosis. This is in agreement with Duffield [19], who stated that the use of NEFA is a better indicator of energy imbalance in prepartum animals than $\mathrm{BHB}$, but $\mathrm{BHB}$ is more useful postpartum. In the present study, a significant positive correlation was established between NEFA and BHB in the sera, suggesting that both parameters are helpful indicators of energy balance during lactation. Blood NEFA and BHB concentrations were not in correlation with the intensity of milk production during lactation, but a significant correlation was observed with DMI and EB.Reist et al. [9] reported a strong correlation among blood NEFA and BHB concentrations and $\mathrm{EB}$ in early lactation dairy cows. $\mathrm{BHB}$ is negatively correlated with food level and it therefore increases in cows fed a good diet in dry and lower quality in post-partum [20].

Blood glucose values in mid lactation cows were within the physiological range $2.5-4.2 \mathrm{mmol} / \mathrm{l}$ [21], whereas hypoglycemia $(2.29 \pm 0.48 \mathrm{mmol} / \mathrm{l})$ was detected in early lactation cows. Taking this criterion into account, early lactation cows had indicative values, but did not display any clinical signs, suggesting that they had a typical subclinical condition. Blood glucose concentrations in early lactation cows were significantly correlated with DMI and EB. In fact, a significant correlation was observed between NEFA values and glucose and BHB and glucose. Similar correlations were observed by other authors [9, 22, 23].Cows in NEB have low rates of glucose and high levels of BHB [22].

Fat infiltration into the liver may also affect the concentration of some blood components. Serum level of TG, is indicator of hepatic functionality, and decreases in their concentration may suggest fat infiltration in the liver $[4,13$, 14]. The concentration of serum TG was significantly lower in ketotic cows compared to healthy cows [4]. These results are showed that TG accumulate in the liver cells of ketotic cows and cause their blood values to decrease. In the present study, TG in the blood was low $(0.12 \pm 0.02 \mathrm{mmol} / 1$ vs $0.15 \pm$ $0.04 \mathrm{mmol} / \mathrm{l}$ ) in both groups of cows, but without significant difference. This study was showed a possibility of the development a fat infiltration of the liver in early lactation cows and was confirmed a significant correlation between TG and glucose, TG and DMI and TG and BHB. When fat infiltrates the liver, a lesion appears in hepatic tissues, and the levels of enzymes that indicate liver injury (AST, GGT, and LDH) are generally augmented [7, 15]. AST values in the present study were statistically higher $(\mathrm{P}<0.05)$ in early lactation cows than in mid lactation cows. If AST activity higher than $100 \mathrm{U} / 1$ is indicative of hepatic lesions [11].These are result early lactation cows in our study suffered from some degree of hepatic lesions, probably due to fat infiltration. Also, a positive correlation was observed between AST activity and NEFA values. In the present study, all data concerning serum AST activities suggested that the process of lipomobilization was sufficient to cause liver lesions in of the early lactating cows.

These metabolic changes were not in correlation with the intensity of milk production during lactation, but a significant correlation was observed between metabolite values and DMI and EB. According to Watheset al.[24], milk yield was independent to nutritional and biochemical parameters during only the first two weeks post-calving but it was significantly higher in cows expressing high levels of BHB and urea at the 4th week. Lower DMI could explain lower concentrations of glucose and $\mathrm{TG}$, and higher concentrations of NEFA, BHB and AST. Negative energy balance could explain lower glucose concentrations and higher NEFA, BHB and AST levels. Insufficient DMI in early lactation is known to lead to NEB with the above mentioned changes occurring in the metabolic profile. Metabolic changes during early lactation were more intensive as a function of EB, compared to mid lactation. These changes are due to both lipolysis and ketogenesis occurring during homeorhetic processes and metabolic adaptation in the liver during early lactation. Several authors reported these changes but with different intensities [5, 9, 22, 23]. 


\section{Conclusions}

In conclusion, on the basis of changes of blood biochemical metabolites, this study suggests that early lactation cows had metabolic disturbances, which were associated with ketosis, and some degree of hepatic lesions, probably due to fat infiltration. These metabolic changes were correlated with DMI and EB, but not with milk yield, and they can serve as useful indicators of the nutritional and metabolic status of dairy cows during lactation.

\section{Acknowledgements}

This study was financially supported by the Ministry of Education and Science, Republic of Serbia, Project TR. 31001 and TR.31062.

\section{REFERENCES}

[1] Veenhuizen JJ, Drackley JK, Richard MJ, Sanderson TP, Miller LD, Joung JW. Metabolic changes in blood and liver during development and early treatment of experimental fatty liver and ketosis in cows. Journal of Dairy Science. 1991. 74: 4238-4253.

[2] Drackley JK. Biology of dairy cows during the transition period: The final frontier? Journal of Dairy Science. 1999. $82: 2259-2273$

[3] Oetzel GR. Monitoring and testing dairy herds for metabolic disease. Veterinary Clinics of North America: Food Animal Practice.2004. 20:651-674.

[4] Djokovic R. Šamanc H, Jovanovic M, Nikolic Z. Blood concentrations of thyroid hormones and lipids in the liver in dairy cows in transitional period. Acta Veterinaria Brno. 2007. 76: 525-532.

[5] Remppis S. Steingass H. Gruber L. Schenkel H. Effects of energy intake on performance, mobilization and retention of body tissue, and metabolic parameters in dairy cows with special regard to effects of pre-partum nutrition on lactation, a review. Asian-Australian Journal of Animal Science. 2011. 24: $540-572$.

[6] Morrow DA, Hilmann D. Dade AW, Kitchen H. Clinical investigation of dairy herd with the fat cow syndrome. Journal of American Veterinary Medicine Assocation.1990.174: 161-167.

[7] Pechova A, Llek J, Halouzka R. Diagnosis and control of the development of hepatic lipidosis in dairy cows in the peri-parturient period. Acta Veterinaria Brno. 1997: 66: 235-243.

[8] Duffield TF, Kelton DF, Leslie KE, Lissemore KD., Lumsden $\mathrm{JH}$. Use of test day milk fat and milk protein to detect subclinical ketosis in dairy cattle in Ontario. Canadian Veterinary Journal. 1997. 38:713-718.

[9] Reist M. Erdin D. von Euw D, Tschuemperlin K. Leuenberger $\mathrm{H}$, Delavaud C, Chilliard Y, Hammon HM, Morel C, Philipona C. Zbinden Y. Kuenzi N. Blum JW. Estimation of energy balance at the individual and herd level using blood and milk traits in high-yielding dairy cows. Journal of Dairy Science. 2002.85: 3314-3327.

[10] Civelek T, Aydin I. Cingi C. Yilmaz O. Kabu M. Serum non-esterified fatty acids and beta-hydroxybutyrate in dairy cows with retained placenta. Pakistan Veterinary Journal. 2011. 31: 341-344.

[11] González FD, Muiño R,Pereira V, Campos R.Relationship among blood indicators of lipomobilization and hepatic function during early lactation in high-yielding dairy cows. Journal of Veterinary Science. 2011 12:-255.

[12] Herdt TH, Leisman JS, Gerloff BJ, Emery RS. Reduction of serum triacylglycerol-rich lipoprotein concentrations in cows with hepatic lipidosis. American Journal of Veterinary Research. 1983. 44: 293-296.

[13] Sevinc M, Basoglu A, Guzelberta H.: Lipid and lipoprotein levels in dairy cows with fatty liver. Turkish Journal of Veterinary and Animal Science. 2003. 27: 295-299.

[14] Djokovic R, Ilic Z, Kurcubic V, Petrovic M, Doskovic V. Functional and morphological state of the liver in Simmental dairy cows during transitional period. Revue de Medecine Veterinaire. 2011. 162: 574-579.

[15] Lubojacka V, Pechova A, Dvorak R, Drastich P, Kummer V, Poul J. Liver steatosis following supplementation with fat in dairy cows diets. Acta Veterinaria Brno.2005. 74: 217-22.

[16] Ferguson JD. Galligan DT, Thomsen, N. Principal descriptors of body condition score in Holstein cows. Journal of Dairy Sci. 1994. 77:2695-2703.

[17] NRC.: Nutrient requirements of Dairy Cattle, pp 13-28, National Academic Press, Washington, DC. 2001.

[18] Cincovic RM, Belic B, Radojcic B, Hristov S, Đokovic R. Influence of lipolysis and ketogenesis to metabolic and hematological parameters in dairy cows during periparturient period. Acta Veterinaria Beograd. 2012. 62: 429-444.

[19] Duffield T. Subclinical ketosis in lactating dairy cattle. Veterinary Clinics of North America: Food Animal Practice.2000. 16: 231-253.

[20] Stockdale CR. Effects of body condition score at calving and feeding various types of concentrate supplements to grazing dairy cows on early lactation performance. Livestock Science. 2008.116:191-202.

[21] Radostis OM, Blood DC, Gay CC, Hinchcliff KW. Veterinary Medicine, A Textbook of the Diseases of Cattle, Sheep, Pigs, Goats and Horses. Ninth Edition W.B. Saunders Company Ltd London New York Philadelphia San Francisco St. Louis Sydney, 2000.

[22] Xia C, Wang Z,Li YF, Niu SL, Xu C, Zhang C, Zhang HY. Effect of hypoglycemia on performances, metabolites, and hormones in periparturient dairy cows. Agriculture Science of China. 2007.6: 505-512.

[23] Laszlo K, Otto S, Viktor J, Laszlone T, Beckers JF, Endre B. Examination of some reproductive indices of peripartal period in relation with energy metabolism in dairy cows. Magyar Allatorvosok Lapja. 2009. 131:259-269.

[24] Wathes DC, Cheng Z, Bourne N, Taylor VJ, Coffey MP, Brotherstone S. Differences between primiparous and multiparous dairy cows in the inter-relationships between metabolic traits, milk yield and body condition score in the periparturient period. Domestic Animal Endocrinology. 2007.33: 203-225. 